\title{
KEBIJAKAN PENGEMBANGAN PASOKAN PANGAN DOMESTIK TELUR AYAM DI KABUPATEN PATI
}

\section{THE POLICY FOR DEVELOPING DOMESTIC FOOD SUPPLY OF CHICKEN EGGS IN PATI REGENCY}

\author{
Suroso \\ Badan Perencanaan Pembangunan Daerah Kabupaten Pati \\ Email:surosopati321@gmail.com
}

Naskah Revisi: 6 April 2018

Naskah Diterima: 12 April 2018

\begin{abstract}
Food supply is very important to ensure adequate food comsumption for community. The objectives of the research are: (1) to analyze the production of chicken eggs; (2) to analyze the consumption of chicken eggs; and (3) to analyze the balance and food supply chain of chicken eggs in the study area.This research used descriptive-quantitative approach. The research used primary and secondary data. Data collecting was conducted by interview and survey. The reserch used descriptive analysis. The research has 3 findings. Firstly, in Pati Regency production of race chicken eggs are 13,008,982 granules equal to 455,922.69 kilograms and the consumption of race chicken eggs are 455,922.69 kilograms so it has minus balance $(-7,465,713.83)$ kilograms of race chicken eggs for a year. Secondly, the production local chicken eggs are 23,355,221 granules eggs equal to 830,745.21 kilograms and the consumption of local chicken eggs are 198,392.25 kilograms so it has surplus balance 632,353 kilograms of local chicken eggs for a year. Thirdly, in composite, the production of chicken eggs is less than consumption of chichen eggs and the supply of chicken eggs in Pati Regency is mostly derived from other regions including: Tuban, Blitar, Lamongan, Nganjuk and Bojonegoro. Then the sale trade of chicken eggs fot outside market is just little especially in the market of Kudus Regency.
\end{abstract}

Keywords: chicken egg, food supply, policy

\section{ABSTRAK}

Pasokan pangan sangat penting untuk menjamin konsumsi pangan memadai bagi masyarakat. Penelitian ini memiliki tujuan: (1) menganalisa tingkat produksi telur ayam; (2) menganalisa tingkat konsumsi telur ayam dan (3) menganalisa neraca dan rantai pasokan pangan komoditas telur ayam di area studi. Penelitian ini menggunakan pendekatan deskriptif-kuantitatif. Data penelitian meliputi data primer dan data sekunder. Pengumpulan data primer dilakukan dengan menggunakan teknik wawancara dan survey. Penelitian ini menggunakan analisis deskriptif. Penelitian ini memiliki 3 temuan. Pertama, Kabupaten Pati memiliki produksi telur ayam ras sebanyak 13.008.982 butir setara dengan 455.922,69 kg dan konsumsi telur ayam ras sebanyak $8.116 .162,95 \mathrm{~kg}$ maka daerah ini memiliki neraca minus $(-7.465 .713,83) \mathrm{kg}$ telur ayam ras per tahun. Kedua, Kabupaten Pati memiliki produksi neto telur ayam buras 23.355 .221 butir setara dengan 830.745,21 kg dan konsumsi telur ayam buras sebanyak 198.392,25 kg maka daerah ini memiliki neraca surplus $632.353 \mathrm{~kg}$ telur ayam buras per tahun. Ketiga, secara komposit, produksi telur di Kabupaten Pati lebih sedikit dibandingkan konsumsi telur dan rantai pasokan pangan komoditas telur ayam sebagian besar didatangkan dari luar daerah meliputi: Tuban, Blitar, Lamongan, Nganjuk dan Bojonegoro. Kemudian perdagangan penjualan telur ayam keluar daerah relatif kecil dengan target pasar Kabupaten Kudus.

Kata kunci: kebijakan, pasokan pangan, telur ayam 


\section{PENDAHULUAN}

\begin{tabular}{llr}
\multicolumn{1}{c}{ Pangan } & sebagai kebutuhan dasar \\
manusia & sangat & menentukan \\
kelangsungan hidup & masyarakat. \\
Ketidakcukupan pangan & berpotensi \\
mengguncang stabilitas sosial dan
\end{tabular} ketahanan nasional. Namun jika pangan tersedia sesuai dengan kebutuhan dan terjangkau daya beli, masyarakat akan memberi dukungan terhadap stabilitas nasional di bidang ekonomi dan politik. Oleh karenanya pangan merupakan barang strategis yang dapat menjadi penentu keamanan, sosial dan politik. Pangan menjadi bagian penting kebijaksanaan ekonomi hampir semua negara (Witoro, dkk., 2006).

Relevan dengan hal tersebut, Business News (2011) menyampaikan bahwa pangan pokok merupakan bahan pangan yang dibutuhkan oleh seluruh masyarakat sehingga harga pangan pokok yang stabil merupakan harapan masyarakat. Harga pangan pokok yang bergejolak (berfluktuasi) merupakan kekhawatiran masyarakat karena hal ini akan berdampak pada daya beli masyarakat yang dapat berdampak secara sosial dan politik. Salah satu komoditas pangan yang memiliki harga fluktuasi adalah telur ayam.

Telur ayam merupakan salah satu pangan strategis. Nuryati dkk (2012) menyampaikan bahwa salah satu produk pangan pokok yang mempunyai harga relatif berfluktuasi adalah telur ayam. Telur merupakan bahan pangan hasil ternak unggas yang memiliki sumber protein hewani, rasanya lezat, mudah dicerna dan bergizi tinggi. Tingkat konsumsi telur lebih besar dari konsumsi hasil ternak lain, karena mudah diperoleh dan harganya relatif murah, sehingga terjangkau bagi masyarakat yang memiliki daya beli rendah.

Prospek usaha peternakan ayam ras petelur di Indonesia menurut Susanto dkk (2015), dinilai sangat baik dilihat dari pasar dalam negeri maupun luar negeri, jika ditinjau dari sisi penawaran dan permintaan. Terkat penawaran, kapasitas produksi peternakan ayam ras petelur di Indonesia masih belum mencapai kapasitas produksi yang memadai. Terkait permintaan, saat ini produksi telur ayam ras baru mencukupi kebutuhan pasar dalam negeri sebesar $65 \%$. Sisanya dipenuhi dari telur ayam kampung, itik, dan puyuh.

Terkait hal tersebut, kondisi daerah Kabupaten Pati terindikasi pemenuhan kebutuhan telur ayam sebagian didatangkan dari luar daerah karena usaha peternakan ayam petelur belum berkembang dengan baik. Penelitian ini memiliki tujuan: (1) menganalisis tingkat produksi telur ayam; (2) menganalisis tingkat konsumsi telur ayam; dan (3) menganalisis kondisi neraca dan rantai pasokan telur ayam di area studi.

\section{TINJAUAN PUSTAKA}

Pangan menurut UU Nomor 18 Tahun 2012 adalah segala sesuatu yang berasal dari sumber hayati dan air, baik yang diolah maupun tidak diolah yang diperuntukan sebagai makanan atau minuman bagi konsumsi manusia, termasuk bahan tambahan pangan, bahan baku pangan, dan bahan lain yang digunakan dalam proses penyiapan, pengolahan, dan/atau pembuatan makanan atau minuman.

\section{Komitmen Pemenuhan Hak Atas Pangan}

Pemenuhan hak atas pangan, merupakan salah satu komponen penting untuk menikmati hak hidup sejahtera lahir dan batin. Pengakuan, penghormatan dan pemenuhan terhadap hak atas pangan di Indonesia dijamin oleh Undang-Undang No. 11 tahun 2005 tentang Kovenan Internasional tentang Hak-Hak Ekonomi Sosial dan Budaya (International Covenant on Economic, Social And Cultural Rights). 
Kovenan Internasional merupakan tindaklanjut komitmen bersama dalam World Food Summit yang diselenggarakan FAO tanggal 13-17 November 1996 di Roma, Italia yang diikuti negara-negara di dunia (termasuk Indonesia). Satu diantara komitmen yang disepakati berbunyi:

"We will implement policies aimed at eradicating poverty and inequality and improving physical and economic access by all, at all times, to sufficient, nutritionally adequate and safe food and its effective utilization".

Komite Hak Ekonomi Sosial dan Budaya PBB, dalam Komentar Umum (General Comment) No.12 Tahun 1999, menyatakan Komite mempertimbangkan bahwa muatan utama Hak atas Pangan yang layak mengandung arti: (a) tersedianya pangan dalam jumlah dan kualitas yang mencukupi untuk memenuhi kebutuhan diet individu, bebas dari bahan-bahan berbahaya, dan dapat diterima oleh budaya-budaya tertentu; dan (b) aksesibilitas dari pangan yang berkelanjutan dan tidak mencampuri penikmatan hak asasi manusia yang lain.

Kewajiban Negara menurut Komentar Umum (General Command) No 12 tahun 1999 diantaranya: (1) Kewajiban utama negara adalah melaksanakan langkah-langkah untuk mencapai perwujudan sepenuhnya hak atas pangan yang layak; (2) Negara wajib bergerak secepat mungkin untuk pemenuhan hak atas pangan; (3) Negara diwajibkan untuk menjamin setiap orang yang berada dalam wilayah yuridiksinya memiliki akses kepada pangan pokok minimum yang mencukupi, cukup gizi dan aman, untuk menjamin agar mereka bebas dari kelaparan; (4) Hak atas pangan bagi setiap orang, membebankan kewajiban kepada Negara untuk menghormati, melindungi dan memenuhi hak atas pangan tersebut; dan (5) Kewajiban negara untuk memenuhi hak atas pangan, mencakup kewajiban untuk memfasilitasi keterjangkauan pangan dan kewajiban untuk menyediakan pangan.

\section{Pengelolaan Ketersediaan dan Pasokan Pangan}

Ketersediaan pangan dapat diusahakan dari hasil produksi pangan, perdagangan pangan atau peredaran pangan. Menurut UU Nomor 18 Tahun 2012, produksi pangan adalah kegiatan atau proses menghasilkan, menyiapkan, mengolah, membuat, mengawetkan, mengemas, mengemas kembali, dan/atau mengubah bentuk pangan. Selanjutnya, perdagangan pangan adalah setiap kegiatan atau serangkaian kegiatan dalam rangka penjualan dan/atau pembelian pangan, termasuk penawaran untuk menjual pangan,dan kegiatan lain yang berkenaan dengan pemindahtanganan pangan dengan memperoleh imbalan. Kemudian peredaran pangan adalah setiap kegiatan atau serangkaian kegiatan dalam rangka penyaluran pangan kepada masyarakat, baik diperdagangkan maupun bantuan sosial.

Terkait ketersediaan pangan, Bank Dunia (2014) menyatakan bahwa Indonesia memiliki sumber daya yang cukup untuk menjamin ketahanan pangan bagi penduduknya. Namun penduduk Indonesia yang belum dapat memenuhi kebutuhan pangan masih banyak. Menurut Suradi (2015), sekitar $30 \%$ rumah tangga di Indonesia, konsumsi pangan masih berada di bawah kebutuhan konsumsi yang semestinya. Lebih dari seperempat anak usia di bawah 5 tahun memiliki berat badan di bawah standar, dimana 8 persen berada dalam kondisi sangat buruk.

UU No 18 Tahun 2012 tentang Pangan dan PP No 68 Tahun 2002 
tentang Ketahanan Pangan, mengamanatkan ketersediaan dan pasokan pangan yang memadai bagi masyarakat. Produksi pangan dan rantai pasokan perdagangan pangan sangat menentukan konisi ketahanan pangan. Rantai pasokan pangan (food supply chain) suatu negara atau daerah dapat dipenuhi melalui pengelolaan produksi pangan dan perdagangan pangan. Ini berarti pemerintah perlu mengelola rantai pasokan pangan dengan baik. Pengelolaan rantai pasokan pangan (food supply chain manajement) menurut Richardus Djokopranoto (2002), adalah integrasi suatu proses bisnis dari end user melalui original supplier (pemasok barang/pelayanan bagi konsumen). Selain itu juga ada yang mengatakan bahwa manajemen rantai pasokan adalah kegiatan transformasi sehingga menjadi produk dalam proses, kemudian menjadi produk jadi dan diteruskan dengan pengiriman kepada konsumen melalui sistem distribusi, kegiatan yang dilakukan mencakup pembelian tradisional dan berbagai kegiatan penting yang berhubungan dengan supplier dan distributor.

\section{METODE PENELITIAN}

Penelitian ini dilakukan di Kabupaten Pati tahun 2017. Penelitian ini menggunakan pendekatan deskriptifkuantitatif. Metode deskriptif merupakan prosedur pemecahan masalah dengan cara menerangkan obyek penelitian didasarkan pada fenomena faktual dan usaha menemukan korelasi aspek-aspek yang sedang diteliti (Nawawi, 1995).

Penelitian ini memiliki 3 variabel: (1) produksi telur ayam; (2) konsumsi telur ayam; dan (3) neraca domestik pasokan telur ayam. Telur ayam dalam studi ini mencakup telur ayam ras dan telur ayam buras.
Data penelitian meliputi data primer dan data skunder yang merupakan data nominal mengenai produksi, konsumsi dan neraca telur ayam. Pengumpulan data skunder dilakukan dengan observasi dokumen. Data produksi dan konsumsi telur ayam bersumber dari BPS. Pengumpulan data primer mengenai rantai pasokan telur ayam dilakukan dengan teknik survei dan wawancara terhadap pedagang antar daerah dengan purposive sampling. Pebisnis (pedagang) yang memiliki ijin usaha dagang komoditas telur ayam sebanyak 7 usaha yang tersebar di 3 Kecamatan yaitu: Sukolilo, Winong dan Juwana. Ada 4 pedagang telur ayam yang menjadi sampel dalam studi ini.

Penelitian ini menggunakan analisis deskriptif. Secara teknis analisis yang digunakan dalam studi ini menggunakan rumus berikut ini:.

1.Produksi Telur Ayam (Deptan, 2007)

a). Produksi telur ayam ras

$$
\begin{aligned}
& P_{\text {net }}=E_{\text {net }} \times C_{1} \ldots \ldots \ldots \ldots(1) \\
& P_{\text {net }}=\text { Produksi neto } \\
& C_{1}=\text { konversi berat per butir }(0,05 \mathrm{~kg}) \\
& \mathrm{E}_{\text {net }}=\mathrm{P}(1-\mathrm{w}) \\
& \mathrm{E}_{\text {net- }}=\text { Produksi neto telur ayam } \\
& \mathrm{P}=\text { produksi bruto } \\
& \mathrm{w}=\text { tercecer } 2,05 \%(0,0205)
\end{aligned}
$$

b). Produksi telur ayam buras

$$
\begin{aligned}
& \mathrm{P}_{\text {net }}=\mathrm{E}_{\text {net }} \times \mathrm{C}_{1} \ldots \ldots \ldots \ldots(2) \\
& \mathrm{P}_{\text {net }}=\text { Produksi neto } \\
& \mathrm{C}_{1}=\text { konversi berat per butir }(0,05 \mathrm{~kg}) \\
& \mathrm{E}_{\text {net }}=\mathrm{P}(1-(\mathrm{s}+\mathrm{w})) \\
& \mathrm{E}_{\text {net- }}=\text { Produksi neto telur ayam } \\
& \mathrm{P} \quad=\text { produksi bruto } \\
& \mathrm{S} \quad=\text { bibit } 25 \%(0,25) \\
& \mathrm{w}=\text { tercecer } 3,86 \%(0,0386)
\end{aligned}
$$

\section{Konsumsi Telur Ayam}

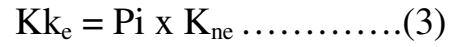

$\mathrm{Kk}_{\mathrm{e}}=$ Konsumsi kumulatif telur

$\mathrm{Pi}=$ jumlah penduduk $\mathrm{i}$

$\mathrm{K}_{\mathrm{ne}}=$ Konsumsi normatif telur perkapita 


\section{Proyeksi Produksi Telur Ayam}

$\mathrm{PPT}=\mathrm{Pa} \times \mathrm{Tp} \times \mathrm{He}$

$\mathrm{PPt}=$ Proyeksi produksi telur ayam telur

$\mathrm{Pa}=$ populasi ayam

$\mathrm{Tp}=$ tingkat produksi

$\mathrm{He}=$ waktu (hari) efektif produksi

\section{HASIL DAN PEMBAHASAN}

Ada 3 substansi yang menjadi pokok pembahasan bagian ini yaitu: (1) produksi telur ayam; (2) konsumsi telur ayam; (3) neraca dan rantai pasokan telur ayam.

\section{Produksi Bruto dan Produksi Neto Telur Ayam}

Produksi bersih telur $\left(\mathrm{E}_{\mathrm{net}}\right)$ adalah produksi bruto dikurangi produksi telur tercecer (w) dengan nilai 0,0207 setara
$2,05 \%$. Secara teknis, pengukuran produksi menjadi produksi neto menggunakan rumus tersebut diatas.

\section{Produksi telur ayam ras}

Menurut BPS (2017), Kabupaten Pati Tahun 2016 memiliki produksi telur ayam ras sebanyak 13.281.248 butir. Produksi bersih telur $\left(E_{\text {net }}\right)$ adalah produksi bruto dikurangi produksi telur tercecer (w) dengan nilai 0,0205 setara $2,05 \%$ maka produksi neto telur ayam ras sebanyak 13.008.982 butir. Nilai konversi telur per butir setara dengan $0,05 \mathrm{~kg}$ sehingga produksi neto telur ayam ras sebanyak 13.008 .982 butir setara dengan 455.922,69 kg. Produksi telur ayam ras di Kabupaten Pati Tahun 2016 ditunjukkan pada Tabel 1.

Tabel 1.

Produksi Telur Ayam Ras di Kabupaten Pati

\begin{tabular}{|c|c|c|c|c|c|c|c|}
\hline \multirow[t]{3}{*}{ No } & \multirow[t]{3}{*}{ Kecamatan } & \multicolumn{6}{|c|}{ Produksi Telur Ayam Ras } \\
\hline & & Produksi & $\mathrm{K}$ & Tercecer & Neto & Konversi & Produksi Neto \\
\hline & & $\mathrm{P}$ (butir) & 1 & $\mathrm{~W}$ & $\overline{E_{\text {net }}}$ & $\mathrm{C} 1$ & $P_{\text {net }(k g)}$ \\
\hline 1 & Sukolilo & 1.130 .561 & 1 & 0,0205 & 1.107 .384 & 0,05 & $55.369,22$ \\
\hline 2 & Kayen & & 1 & 0,0205 & - & 0,05 & - \\
\hline 3 & Tambakromo & & 1 & 0,0205 & - & 0,05 & - \\
\hline 4 & Winong & 82.941 & 1 & 0,0205 & 81.241 & 0,05 & $4.062,04$ \\
\hline 5 & Pucakwangi & 281.708 & 1 & 0,0205 & 275.933 & 0,05 & $13.796,65$ \\
\hline 6 & Jaken & & 1 & 0,0205 & - & 0,05 & - \\
\hline 7 & Batangan & 822.454 & 1 & 0,0205 & 805.594 & 0,05 & $40.279,68$ \\
\hline 8 & Juwana & 576.000 & 1 & 0,0205 & 564.192 & 0,05 & $28.209,60$ \\
\hline 9 & Jakenan & & 1 & 0,0205 & - & 0,05 & - \\
\hline 10 & Pati & & 1 & 0,0205 & - & 0,05 & - \\
\hline 11 & Gabus & 16.896 & 1 & 0,0205 & 16.550 & 0,05 & 827,48 \\
\hline 12 & Margorejo & 457.553 & 1 & 0,0205 & 448.173 & 0,05 & $22.408,66$ \\
\hline 13 & Gembong & & 1 & 0,0205 & - & 0,05 & - \\
\hline 14 & Tlogowungu & 205.243 & 1 & 0,0205 & 201.036 & 0,05 & $10.051,78$ \\
\hline 15 & Wedarijaksa & 35.520 & 1 & 0,0205 & 34.792 & 0,05 & $1.739,59$ \\
\hline 16 & Trangkil & 4.079 .934 & 1 & 0,0205 & 3.996 .295 & 0,05 & $199.814,77$ \\
\hline 17 & Margoyoso & 156.100 & 1 & 0,0205 & 152.900 & 0,05 & $7.645,00$ \\
\hline 18 & Gunungwungkal & 46.911 & 1 & 0,0205 & 45.949 & 0,05 & $2.297,47$ \\
\hline 19 & Cluwak & 2.596 .237 & 1 & 0,0205 & 2.543 .014 & 0,05 & $127.150,71$ \\
\hline 20 & Tayu & 997.362 & 1 & 0,0205 & 976.916 & 0,05 & $48.845,80$ \\
\hline \multirow[t]{2}{*}{21} & Dukuhseti & 1.795 .828 & 1 & 0,0205 & 1.759 .014 & 0,05 & $87.950,68$ \\
\hline & Kabupaten Pati & 13.281 .248 & & & 13.008 .982 & & $455.922,69$ \\
\hline
\end{tabular}

(Data diolah: BPS, 2017) 


\section{Produksi Telur Ayam Buras}

Kabupaten Pati Tahun 2016 memiliki produksi telur ayam buras sebanyak 23.355.221 butir (BPS,2017). Produksi bersih telur $\left(\mathrm{P}_{\text {net }}\right)$ adalah produksi bruto dikurangi kebutuhan bibit $25 \%(0,25)$, produksi telur tercecer (w) Tahun 2016 ditunjukkan dengan nilai
0,0386 setara 3,86\% dan nilai konversi telur per butir setara dengan $0,05 \mathrm{~kg}$. Hasil perhitungan menunjukkan produksi bruto telur ayam buras sebanyak 23.355.221 butir setara dengan produksi neto $830.745,21 \mathrm{~kg}$. Produksi telur ayam buras di Kabupaten Pati ditunjukkan pada Tabel 2.

Tabel 2.

Produksi Telur Ayam Buras Neto di Kabupaten Pati

\begin{tabular}{|c|c|c|c|c|c|c|c|}
\hline \multirow[t]{3}{*}{ No } & \multirow[t]{3}{*}{ Kecamatan } & \multicolumn{6}{|c|}{ Produksi Telur Ayam Buras } \\
\hline & & Produksi & $\mathrm{K}$ & Bibit & Tercecer & Konversi & Prod. Neto \\
\hline & & $\mathrm{P}$ (butir) & 1 & s & $\mathrm{w}$ & $\mathrm{C} 2$ & $\mathrm{P}_{\text {net }(\mathrm{kg})}$ \\
\hline 1 & Sukolilo & 1.242 .706 & 1 & 0,25 & 0,0386 & 0,05 & $44.203,05$ \\
\hline 2 & Kayen & 2.337 .090 & 1 & 0,25 & 0,0386 & 0,05 & $83.130,29$ \\
\hline 3 & Tambakromo & 117.152 & 1 & 0,25 & 0,0386 & 0,05 & $4.167,10$ \\
\hline 4 & Winong & 806.521 & 1 & 0,25 & 0,0386 & 0,05 & $28.687,95$ \\
\hline 5 & Pucakwangi & 2.579 .068 & 1 & 0,25 & 0,0386 & 0,05 & $91.737,45$ \\
\hline 6 & Jaken & 845.617 & 1 & 0,25 & 0,0386 & 0,05 & $30.078,60$ \\
\hline 7 & Batangan & 231.514 & 1 & 0,25 & 0,0386 & 0,05 & $8.234,95$ \\
\hline 8 & Juwana & 687.540 & 1 & 0,25 & 0,0386 & 0,05 & $24.455,80$ \\
\hline 9 & Jakenan & 752.417 & 1 & 0,25 & 0,0386 & 0,05 & $26.763,47$ \\
\hline 10 & Pati & 351.379 & 1 & 0,25 & 0,0386 & 0,05 & $12.498,55$ \\
\hline 11 & Gabus & 1.026 .291 & 1 & 0,25 & 0,0386 & 0,05 & $36.505,17$ \\
\hline 12 & Margorejo & 29.546 & 1 & 0,25 & 0,0386 & 0,05 & $1.050,95$ \\
\hline 13 & Gembong & 1.097 .460 & 1 & 0,25 & 0,0386 & 0,05 & $39.036,65$ \\
\hline 14 & Tlogowungu & 126.562 & 1 & 0,25 & 0,0386 & 0,05 & $4.501,81$ \\
\hline 15 & Wedarijaksa & 833.774 & 1 & 0,25 & 0,0386 & 0,05 & $29.657,34$ \\
\hline 16 & Trangkil & 193.406 & 1 & 0,25 & 0,0386 & 0,05 & $6.879,45$ \\
\hline 17 & Margoyoso & 6.528 .933 & 1 & 0,25 & 0,0386 & 0,05 & $232.234,15$ \\
\hline 18 & Gunungwungkal & 1.710 .950 & 1 & 0,25 & 0,0386 & 0,05 & $60.858,49$ \\
\hline 19 & Cluwak & 1.170 .400 & 1 & 0,25 & 0,0386 & 0,05 & $41.631,13$ \\
\hline 20 & Tayu & 232.344 & 1 & 0,25 & 0,0386 & 0,05 & $8.264,48$ \\
\hline \multirow[t]{2}{*}{21} & Dukuhseti & 454.551 & 1 & 0,25 & 0,0386 & 0,05 & $16.168,38$ \\
\hline & Kabupaten Pati & 23.355.221 & & & & & $830.745,21$ \\
\hline
\end{tabular}

(Data diolah: BPS, 2017)

Kebutuhan Domestik Konsumsi Telur Ayam di Kabupaten Pati

Konsumsi telur merupakan akumulasi konsumsi perkapita selama setahun dari seluruh penduduk yang menjadi basis penghitungan. Ada 2 kategori telur yang dikonsumsi masyarakat yaitu: telur ayam ras dan telur ayam buras.

Pertama, konsumsi telur ayam ras menurut hasil survey BPS menyatakan bahwa konsumsi telur ayam ras per kapita per minggu: (1) tahun 2011 sebanyak 0,127 kg; (2) tahun 2012 sebanyak 0,125 kg; (3) tahun 2013 sebanyak 0,118 kg; (4) tahun 2014 sebanyak 0,121 kg; dan (5) tahun 2015 sebanyak $0,117 \mathrm{~kg}$. Ini berarti rerata konsumsi per kapita telur ayam ras per minggu sebanyak $0,122 \mathrm{~kg}$. Bila satu minggu sama dengan 7 hari dan satu tahun sama dengan 365 hari maka rerata 
konsumsi per kapita telur ayam ras per tahun $6,341 \mathrm{~kg}$.

Kedua, konsumsi telur ayam buras per kapita per minggu: (1) tahun 2011 sebanyak 0,072 butir ; (2) tahun 2012 sebanyak 0,053 butir; (3) tahun 2013 sebanyak 0,050 butir; (4) tahun 2014 sebanyak 0,050 butir; dan (5) tahun 2015 sebanyak 0,072 butir. Ini berarti rerata konsumsi per kapita telur ayam buras per minggu sebanyak 0,059 butir. Bila satu minggu sama dengan 7 hari dan satu tahun sama dengan 365 hari maka rerata konsumsi per kapita telur ayam buras setahun sebesar 3,097 butir dan jika nilai konversi 1 butir telur setara dengan $0,05 \mathrm{~kg}$ maka rerata konsumsi per kapita telur ayam buras setahun setara dengan $0,155 \mathrm{~kg}$ yang ditunjukkan pada Tabel 3.

Tabel 3.

Standar Normatif Konsumsi Telur Per Kapita

\begin{tabular}{lllllr}
\hline No & Tahun & \multicolumn{2}{c}{$\begin{array}{c}\text { Konsumsi Telur Ayam Ras } \\
\text { Perkapita (kg) }\end{array}$} & \multicolumn{2}{c}{$\begin{array}{c}\text { Konsumsi Telur Ayam Buras } \\
\text { Perkapita (butir) }\end{array}$} \\
\cline { 3 - 6 } & & $\begin{array}{l}\text { Per Minggu } \\
\text { (7 hari) }\end{array}$ & $\begin{array}{l}\text { Per Tahun } \\
\text { (365 hari) }\end{array}$ & $\begin{array}{l}\text { Per Minggu } \\
\text { (7 hari) }\end{array}$ & $\begin{array}{c}\text { Per Tahun } \\
\text { (365 hari) }\end{array}$ \\
\hline 1 & 2011 & 0,127 & 6,622 & 0,072 & 3,754 \\
2 & 2012 & 0,125 & 6,518 & 0,053 & 2,764 \\
3 & 2013 & 0,118 & 6,153 & 0,050 & 2,607 \\
4 & 2014 & 0,121 & 6,309 & 0,050 & 2,607 \\
5 & 2015 & 0,117 & 6,101 & 0,072 & 3,754 \\
\hline & Rerata & 0,122 & 6,361 & 0,059 & 0,097 \\
\hline
\end{tabular}

(Sumber data diolah: BPS, 2016)

Tahun 2016 Kabupaten Pati memiliki penduduk sebanyak 1.279.950 orang (Disdukcapil, 2017). Bila konsumsi telur ayam ras perkapita per tahun sebanyak $6,341 \mathrm{~kg}$ maka kumulatif konsumsi telur ayam ras untuk penduduk selama setahun sebanyak 8.116.162,95 kg. Kemudian konsumsi telur ayam buras perkapita per tahun sebanyak 3,097 butir atau setara 0,155 $\mathrm{kg}$ maka kumulatif konsumsi telur ayam buras untuk penduduk 1.279.950 orang selama setahun sebanyak 198.392,25 kg.

\section{Neraca Produksi dan Konsumsi Telur Ayam}

Tahun 2016 Kabupaten Pati memiliki produksi neto telur ayam ras sebanyak 13.008 .982 butir setara dengan $455.922,69 \mathrm{~kg}$. Kemudian konsumsi telur ayam ras masyarakat domestik selama setahun sebanyak $8.116 .162,95 \mathrm{~kg}$ maka daerah ini memiliki neraca minus $(-7.465 .713,83) \mathrm{kg}$ telur ayam ras.
Berikutnya, Kabupaten Pati memiliki produksi neto telur ayam buras sebanyak 23.355.221 butir setara dengan $830.745,21 \mathrm{~kg}$. Sisi lain, konsumsi telur ayam buras masyarakat domestik selama setahun sebanyak 198.392,25 kg. Ini berarti daerah ini memiliki neraca surplus $632.353 \mathrm{~kg}$ telur ayam buras tahun 2016 .

Secara komposit produksi telur ayam ras dan buras sebanyak $1.481 .194,33 \mathrm{~kg}$ dengan rincian produksi telur ayam ras $650.449,12 \mathrm{~kg}$ dan produksi telur ayam buras sebanyak $830.745,21 \mathrm{~kg}$. Sisi lain konsumsi telur ayam ras $8.116 .162,95 \mathrm{~kg}$ dan konsumsi telur ayam buras 198.392,25 maka konsumsi komposit telur ayam sebanyak 8.314.555,20 kg maka Kabupaten Pati memiiki neraca minus (defisit) 6.833.360,87 kg / tahun. Kondisi neraca pangan telur ayam di Kabupaten Pati ditunjukkan Tabel 4. 
Tabel 4.

Neraca Produksi dan Konsumsi Telur Ayam di Kabupaten Pati

\begin{tabular}{|c|c|c|c|}
\hline \multicolumn{4}{|c|}{ Neraca Telur Ayam Ras } \\
\hline \multicolumn{2}{|c|}{ Produksi Telur Ayam Ras (kg) } & \multicolumn{2}{|c|}{ Konsumsi Telur Ayam Ras (kg) } \\
\hline Faktor determinan & Jumlah & Faktor Determinan & Jumlah \\
\hline Produksi bruto (butir) & 13.281 .248 & Konsumsi perkapita/ tahun & 6,341 \\
\hline Tercecer (w) 2,05\% & 272.266 & Penduduk tahun 2016 & 1.279 .950 \\
\hline Konversi 1 butir $=(\mathrm{kg})$ & 0,05 & Konsumsi penduduk kumulatif & $8.116 .162,95$ \\
\hline Produksi neto $(\mathrm{kg})$ & $650.449,12$ & & \\
\hline Saldo Minus (kg) & $-7.465 .713,83$ & & \\
\hline \multicolumn{4}{|c|}{ Neraca Telur Ayam Buras } \\
\hline \multicolumn{2}{|c|}{ Produksi Telur Ayam Buras (kg) } & \multicolumn{2}{|c|}{ Konsumsi Telur Ayam Buras (kg) } \\
\hline Faktor determinan & Jumlah & Faktor Determinan & Jumlah \\
\hline Produksi bruto (butir) & 23.355 .221 & Konsumsi perkapita/ tahun & 0,155 \\
\hline Bibit (s) $25 \%$ & 5.838 .805 & Penduduk tahun 2016 & 1.279 .950 \\
\hline Tercecer (w) 3,86\% & 901.512 & Konsumsi penduduk kumulatif & $198.392,25$ \\
\hline Konversi 1 butir $=(\mathrm{kg})$ & 0,05 & Saldo Plus (kg) & 632.353 \\
\hline Produksi neto $(\mathrm{kg})$ & $830.745,21$ & & \\
\hline \multicolumn{4}{|c|}{ Neraca Komposit Telur Ayam } \\
\hline Produksi Telur Ayam (kg) & & Konsumsi Telur Ayam (kg) & \\
\hline Produksi neto telur ras & $650.449,12$ & Konsumsi telur ras & $8.116 .162,95$ \\
\hline Produksi neto telur buras & $830.745,21$ & Konsumsi telur buras & $198.392,25$ \\
\hline Total produksi telur & $1.481 .194,33$ & Total konsumsi telur & $8.314 .555,20$ \\
\hline Saldo minus & $-6.833 .360,87$ & & \\
\hline
\end{tabular}

(Sumber data diolah: BPS, 2017)

\section{Rantai Pasokan Pangan Komoditas Telur Ayam}

Rantai pasokan pangan komoditas telur merupakan kondisi perdagangan pangan komoditas telur antar daerah yang terjadi di area studi. Pebisnis yang memiliki usaha dagang berijin komoditas telur ayam di Kabupaten Pati sebanyak 7 usaha yang tersebar di 3 Kecamatan yaitu: Sukolilo, Winong dan Juwana. Pasokan pangan komoditas telur ayam sebagian besar didatangkan dari daerah lain. Ada 4 dari 7 pebisnis komoditas telur ayam yang diwawancarai dalam studi ini.

Pertama, Rusmiyati memiliki rerata penjualan 1 ton per bulan. Proxi penjualan satu tahun sebanyak 12 ton. Penjualan telur ayam keluar daerah kira kira 3 ton (25\%) dengan daerah pemasaran di Kudus. Selebihnya 9 ton (75 \%) dijual di pasar domestik Kabupaten Pati. Barang dagangan diperoleh dari luar daerah sebanyak 12 ton (100\%), dari Tuban dan tidak ada yang dibeli dari lokal daerah.

Kedua, CV Duta Telur (Arifin) memiliki rerata penjualan telur ayam 3 ton per bulan. Proxi penjualan telur ayam setahun 36 ton. Penjualan domestik 36 ton $(100 \%)$ dan penjualan telur ayam ke luar daerah $0(0 \%)$. Barang dagangan tersebut diperoleh dari luar daerah 36 ton (100\%), dari Blitar dan tidak ada yang dibeli dari lokal daerah.

Ketiga, pebisnis 3 (Sunar) memiliki rerata penjualan telur ayam sebanyak 6 ton per bulan. Proxi penjualan telur ayam satu tahun sebanyak 72 ton. Penjualan telur ayam pada pasar domestik 72 ton $(100 \%)$ dan penjualan telur ayam ke luar daerah tidak ada. Barang dagangan diperoleh dari luar daerah sebanyak 72 ton (100\%), dari Lamongan, Nganjuk, Bojonegoro dan tidak ada yang dibeli dari lokal daerah setempat. 
Keempat, Pebisnis 4 (Suharno) memiliki rerata penjualan telur ayam sebanyak 6 ton sampai 7 ton per bulan. Proxi penjualan satu tahun sebanyak 78 ton. Penjualan telur ayam pada pasar domestik 78 ton (100\%), sedangkan penjualan telur ayam ke luar daerah tidak ada (0\%). Barang dagangan tersebut diperoleh dari luar daerah sebanyak 78 ton (100\%), dari Lamongan, Nganjuk, serta Bojonegoro dan tidak ada telur (dagangan) yang dibeli dari lokal daerah. Rantai pasokan pangan komoditas telur ayam ditunjukkan Tabel 5.

\section{Tabel 5.}

Rantai Pasokan Pangan Komoditas Telur Ayam di Kabupaten Pati

\begin{tabular}{|c|c|c|c|c|c|c|}
\hline \multirow[t]{2}{*}{ No } & \multirow[t]{2}{*}{ Pebisnis } & \multicolumn{3}{|c|}{ Penjualan Barang 1 tahun (ton) } & \multicolumn{2}{|c|}{ Pembelian Barang 1 th (ton) } \\
\hline & & lokal & Expor & Daerah Expor & Impor & Daerah Asal \\
\hline 1 & Rusmiyati & 9 & 3 & Kudus & 12 & Tuban \\
\hline 2 & $\begin{array}{l}\text { Duta Telur } \\
\text { /Arifin }\end{array}$ & 36 & 0 & ( & 36 & Blitar \\
\hline 3 & Sunar & 72 & 0 & c & 72 & $\begin{array}{l}\text { Lamongan, } \\
\text { Nganjuk,bojonegoro }\end{array}$ \\
\hline 4 & Suharto & 78 & 0 & & 78 & $\begin{array}{l}\text { Lamongan, } \\
\text { Nganjuk,bojonegoro }\end{array}$ \\
\hline & Jumlah & 192 & 3 & & 198 & \\
\hline
\end{tabular}

Berdasarkan uraian diatas menunjukkan bahwa rantai pasokan pangan komoditas telur ayam yang berada pada pebisnis/pedagang umumnya didatangkan dari luar dan hanya sedikit yang dijual keluar daerah. Import atau pembelian telur ayam dari luar daerah meliputi: Tuban, Blitar, Lamongan, Nganjuk dan Bojonegoro.

Perlu diketahui bahwa jumlah pasokan tersebut diatas (198 ton per tahun) hanya pasokan yang dilakukan oleh 4 usaha dagang. Sementara tiga usaha dagang berijin komoditas ayam lainnya belum masuk perhitungan. Pasokan telur ayam dari luar daerah juga banyak dilakukan lewat pengusaha retail supermaket dan minimarket tidak masuk pembahasan disini.

Rantai pasokan telur ayam lebih menekankan pada daerah asal pasokan sedangkan jumlah telur ayam telah dibahas pada bagian produksi, konsumsi dan neraca bagian sebelumnya.

\section{Kebijakan Pengembangan Peternakan untuk Memenuhi Pasokan Telur Ayam}

Kabupaten Pati memiliki neraca minus $(-7.465 .713,83) \mathrm{kg}$ telur ayam ras dan neraca surplus $632.353 \mathrm{~kg}$ telur ayam buras. Secara komposit, daerah ini memiliki neraca minus antara produksi dan konsumsi telur ayam sebanyak 6.833.360,87 kg per tahun. Bila swasembada pangan ingin dicapai, pemenuhan kebutuhan telur ayam ras ingin dilakukan melalui produksi lokal maka pengembangan peternakan ayam telur perlu dikembangkan. Guna memenuhi harapan itu dibutuhkan peternakan ayam petelur dengan jumlah yang memadai.

Terkait usaha peternakan ayam petelur, Salele dkk (2014) menyampaikan bahwa ayam ras petelur mulai berproduksi pada umur 17 minggu. Produksi puncak ayam petelur saat umur 28 minggu dan diafkir pada umur 82 minggu karena saat ternak ayam berumur di atas 82 minggu, produksi telur relatif rendah. Penelitian dilakukan pada 2 perusahaan.

Pertama, perusahaan CV. Nawanua Farm memiliki populasi 21.000 ekor saat DOC tetapi pada saat berproduksi populasi sebanyak 19.934 ekor. Ayam umur 17 minggu mulai berproduksi 20,04\% dan terus bertambah 
dengan puncak produksi bertelur dicapai pada umur 28 minggu dengan tingkat produksi mencapai 93,86\%. Kemudian terus menurun dan diafkir saat ternak ayam petelur berumur 82 minggu dengan tingkat produksi 49,67\%.

Kedua, perusahaan UD. Kakaskasen Indah memiliki populasi ayam petelur 60.000 ekor saat DOC tetapi pada saat berproduksi populasi sebanyak 57.383 ekor dengan produksi awal (umur 17 mingggu) sebanyak 21,20\%. Puncak produksi bertelur dicapai pada umur 28 minggu dengan produksi mencapai 93,04\% . Setelah masa puncak, produksi terus menurun dan diafkir ketika ayam berumur 82 minggu dengan tingkat produksi 51,74\%.

Ini berarti mulai awal produksi pada umur 5 bulan dan berakhir pada umur 20 bulan maka ayam berproduksi efektif selama 15 bulan. Dengan kata lain, konversi waktu efektif bertelur sebesar 0,75 (75 \%). Kemudian Hen day (HD), persentase produksi telur yang dihasilkan oleh ayam produktif per hari rata-rata produksi $80 \%$ dengan HD mencapai puncak produksi pada angka $93 \%$.

Konversi waktu efektif bertelur sebesar 0,75 (75\%). Jika waktu 1 tahun 365 hari maka jumlah hari efektif bertelur 274 hari. Hen day (HD), persentase produksi telur yang dihasilkan oleh ayam per hari rata-rata produksi $80 \%(0,80)$ maka produksi telur tiap ekor ayam sebanyak 219 butir setahun. Telur tercecer $(2,05 \%)$ setara dengan 4,4895 butir maka produksi telur neto 214,5105 butir. Konversi berat telur per butir 0,05 $\mathrm{kg}$ maka produksi telur neto setara dengan 10,72553 kg per ekor per tahun. Ini berarti peternakan ayam petelur yang diperlukan untuk menghasilkan telur ayam 7.465.713,83 sebanyak 696.070 ekor. Kabupaten Pati memiliki neraca minus $(-7.465 .713,83) \mathrm{kg}$ telur ayam ras. Bila daerah ini menginginkan swasembada pangan komoditas telur ayam ras maka kebijakan pengembangan peternakan ayam petelur diperlukan minimal 696.070 ekor dengan tingkat produksi per ekor $10,72553 \mathrm{~kg}$ per tahun.

\section{KESIMPULAN DAN SARAN}

\section{Kesimpulan}

Berdasarkan uraian sebelumnya, penelitian ini memiliki kesimpulan sebagai berikut:

1). Produksi telur ayam ras sebanyak 13.008.982 butir. Nilai konversi telur per butir setara dengan $0,05 \mathrm{~kg}$ sehingga produksi neto telur ayam ras setara dengan $455.922,69 \mathrm{~kg}$.

2). Rerata konsumsi per kapita telur ayam ras per tahun $6,36 \mathrm{~kg}$, jumlah penduduk sebanyak 1.279 .950 orang maka kumulatif konsumsi telur ayam ras setahun sebanyak $8.116 .162,95$ $\mathrm{kg}$.

3). Kabupaten Pati memiliki produksi telur ayam ras sebanyak 13.008 .982 butir setara dengan 455.922,69 kg dan konsumsi telur ayam ras 8.116.162,95 kg per tahun maka daerah ini memiliki neraca minus (7.465.713,83) kg untuk telur ayam ras per tahun.

4). Produksi telur ayam buras sebanyak 23.355.221 butir, kebutuhan bibit 25 $\%(0,25)$, telur tercecer (w) 0,0386 setara 3,86\% dan nilai konversi telur per butir $0,05 \mathrm{~kg}$ maka produksi telur ayam buras setara dengan $830.745,21$ $\mathrm{kg}$.

5). Rerata konsumsi per kapita telur ayam buras setahun sebesar 3,097 butir, nilai konversi 1 butir telur 0,05 $\mathrm{kg}$ maka rerata konsumsi per kapita telur ayam buras setahun setara dengan $0,155 \mathrm{~kg}$ dan bila penduduk 1.279.950 orang sehingga kumulatif konsumsi telur ayam buras selama setahun sebanyak $198.392,25 \mathrm{~kg}$.

6). Kabupaten Pati memiliki produksi neto telur ayam buras sebanyak 
23.355.221 butir setara dengan $830.745,21 \mathrm{~kg}$ dan konsumsi telur ayam buras masyarakat domestik selama setahun sebanyak 198.392,25 $\mathrm{kg}$ maka daerah ini memiliki neraca surplus $632.353 \mathrm{~kg}$ untuk pangan komoditas telur ayam buras.

7). Secara komposit produksi telur ayam ras dan buras sebanyak 1.481.194,33 $\mathrm{kg}$ (produksi telur ayam ras $650.449,12 \mathrm{~kg}$ dan produksi telur ayam buras $830.745,21 \mathrm{~kg}$ ). Sisi lain konsumsi komposit telur ayam sebanyak 8.314.555,20 kg (konsumsi telur ayam ras $8.116 .162,95 \mathrm{~kg}$ dan konsumsi telur ayam buras 198.392,25) maka Kabupaten Pati memiliki neraca minus (defisit) 6.833.360,87 kg / tahun untuk komoditi telur ayam.

8). Rantai pasokan pangan komoditas telur ayam di Kabupaten Pati sebagian besar didatangkan dari luar daerah yaitu: Tuban, Blitar, Lamongan, Nganjuk dan Bojonegoro. Kemudian perdagangan penjualan telur ayam keluar daerah relatif kecil dengan target pasar Kabupaten Kudus.

\section{Saran}

Relevan dengan hasil temuan tersebut diatas, kebijakan pengembangan pasokan pangan domestik telur ayam agar diarahkan pada 2 strategi. Pertama, Kebutuhan telur ayam buras sudah terpenuhi dengan kondisi neraca surplus $632.353 \mathrm{~kg}$ untuk pangan komoditas telur ayam buras agar terus dijaga dan kelebihan produksi ini dibandingkan konsumsi lokal dapat dipasarkan keluar daerah. Kedua, Kabupaten Pati memiliki neraca minus $(-7.465 .713,83) \mathrm{kg}$ untuk telur ayam ras per tahun. Pemerintah dapat mendorong usaha peternakan ayam petelur. Guna memenuhi kecukupan konsumsi lokal daerah dibutuhkan pengembangan peternakan ayam petelur sedikitnya 696.070 ekor. Bila ini dilakukan maka ada harapan untuk swasembada pangan komoditas telur.

\section{DAFTAR PUSTAKA}

Bank Dunia. (2014). Pangan untuk Indonesia. Indonesian Policy Briefs. Jakarta: Bank Dunia.

Badan Pusat Statistik. (2017). Kabupaten Pati Dalam Angka. Pati: BPS Kabupaten Pati.

Business News. (2011). Lonjakan harga Telur Menjelang Puasa dan Lebaran. Business News, Juli, 2011.

Departemen Pertanian. (2007). Peta Akses Pangan Pedesaan. Jakarta: Badan Ketahanan Pangan.

Djokopranoto, R. Richardus E. I. (2002). Konsep Manajemen Supply Chain. Jakarta: PT. Gramedia Widiasarana Indonesia.

FAO. (1996). World Food Summit. 13-17 November 1996. Roma: FAO.

Kementan. (2016). Statistik Makro Sektor Pertanian. Jakarta: Pusat Data dan Sistem Informasi Pertanian, Kementerian Pertanian.

Nawawi, H. (1995). Metode Penelitian Bidang Sosial. Yogyakarta: Gajah Mada University Press.

Nuryati, Y., Nur, Y. H. (2012). Variabilitas Harga Telur Ayam Ras di Indonesia. Buletin Ilmiah Litbang Perdagangan, 6(2), 235252.

Pemerintah Republik Indonesia. (2002). Peraturan Pemerintah Nomor 68 Tahun 2002 tentang Ketahanan Pangan. Jakarta: Kemenkum dan HAM. 
Pemerintah Republik Indonesia. (2005).

Undang-Undang Nomor 11 Tahun 2005 tentang Kovenan

Internasional tentang Hak-Hak Ekonomi Sosial dan Budaya. Jakarta: Kemenkum dan HAM.

Pemerintah Republik Indonesia. (2012). Undang-Undang Nomor 18 Tahun 2012 tentang Pangan. Jakarta: Kemenkum dan HAM.

Salele, C. C. L., Roimpandey, B., Massie, M. T., Waleleng, P. O. V. (2014). Ayam Analisis Penggunaan aktor Produksi Pada Perusahaan Ras Petelur (Studi Kasus Pada UD. Kakaskasen Indah Dan CV. Nawanua Farm). Jurnal Zootek, 34 (Edisi Khusus), 1-14

Suradi. (2015). Kebutuhan Pangan bagi Rumah Tangga Miskin. Sosio Informa, 01(1), 1-12.

Susanto, E., Raharja, G. A., Muhammad, A. (2015). Analisis Faktor-Faktor yang Mempengaruhi Minat Konsumen Terhadap Pembelian Telur Ayam Ras di Pasar Wilayah Kecamatan Babat Kabupaten Lamongan. Jurnal Ternak, 06(01), $1-21$

UN. (1999). General Comment No 12 tahun 1999. New York: Komite Hak Ekonomi Sosial dan Budaya, PBB

Witoro, N. Y., Sihaloho, M. (2006). Lumbung Pangan: Jalan Menuju Keterjaminan Pangan. Bogor: Koalisi Rakyat untuk Kedaulatan Pangan (KRKP), Sindangbarang

\section{BIODATA PENULIS}

Suroso, lahir 19 Maret 1966 di Kabupaten Pati Jawa Tengah. Magister Perencanaan Kota dan Daerah Universitas Gajah Mada. Bekerja di Badan Perencanaan Pembangunan Daerah Kabupaten Pati sebagai Peneliti Madya 